\title{
REFLECTIONS ON CULTURAL SPECIFICITY AND DYSTOPIAN STANDARDIZATION IN CHINUA ACHEBE'S NOVELS
}

\author{
Cristina CHIFANE* \\ Independent scholar, Brăila, Romania \\ Liviu-Augustin CHIFANE $^{* *}$ \\ PhD Candidate, "Dunărea de Jos” University, Galați, Romania
}

\begin{abstract}
Although tackling Chinua Achebe's novels as illustrative pieces of postcolonial African literature, this article moves a step further in tracking down the elements projecting these literary texts into universalization. The major aim is to highlight the stylistic differences between the novels making up the African trilogy (Things Fall Apart - 1958, No Longer at Ease - 1960, Arrow of God - 1964) and his subsequent masterpieces A Man of the People (1966) and Anthills of the Savannah (1987). If the African trilogy particularly relies on and therefore has been analyzed in terms of culture-specific items and postcolonial issues, the other two novels acquire new dimensions, giving birth to what can be called dystopian standardization characteristic not only of a certain space or time, but of any society fighting corruption and abusive political systems inevitably leading to oppressive regimes, chaos and collapse.
\end{abstract}

Keywords: postcolonial literature, cultural difference, power relationships, subaltern, dystopian novels

\section{INTRODUCTORY REMARKS}

Considering their cultural specificity and anticolonial message, the novels in the African trilogy (Things Fall Apart - 1958, No Longer at Ease - 1960, Arrow of God - 1964) reflect Chinua Achebe's intention to recuperate and preserve the African legacy: "I would be quite satisfied if my novels (especially the ones set

\footnotetext{
*cristinachifane@yahoo.com

**liviu_aug@yahoo.com
} 
in the past) did more than teach my readers that their past-with all its imperfections-was not one long night of savagery from which the first Europeans acting on God's behalf delivered them" ("The Novelist" 45). The Nigerian writer brilliantly uses his three protagonists (the great Umofia warrior and tribesman Okonkwo in Things Fall Apart, Ezeulu, the chief priest of Umuaro in Arrow of God and Obi, Okonkwo's England-trained nephew in No Longer at Ease) to shed some light on the social, political, economic and cultural transformations before, during and after British colonization. What is more, he skillfully dismantles the dichotomy savage-civilized and turns his novels into powerful instruments against colonial oppression and means of undermining colonial discourse.

Chinua Achebe's novels belonging to the African trilogy have become a part of the "vigorous and persistent debate in African literature between the demand for a recognition of the Africanness of literature and the rejection of universal readings.” (Ashcroft, Griffiths, Tiffin, The Empire Writes Back 125). With an implicit ideological function, these novels gradually follow the complex process of decolonization expressed by Fanon in both Black Skin, White Masks and The Wretched of the Earth. In Fanon's spirit, Achebe rejects the mythicization of the pre-colonial past, but also the universalism label applied according to Euro-American standards, values and forms: "I should like to see the word universal banned altogether from discussions of African literature until such a time as people cease to use it as a synonym for the narrow, self-serving parochialism of Europe" (Morning Yet 13). Although it tracks down the elements projecting the novels into universalization, this article does not actually oppose Achebe's view. It simply does not fall into the trap of unilateralism, an understandable strong reaction to imperialist policies or the perpetuation of a false nationalism. In time, Achebe himself changed his stylistic approach to fiction. His last two novels, A Man of the People (1966) and Anthills of the Savannah (1987) express his option for what can be called dystopian standardization, that is, the portrayal of social and political systems where the individual is suffocating under the yoke of corruption and an insatiable thirst for power. By describing abusive political regimes, Achebe remains true to his fight against oppression and imperialism, but his message targets a much larger audience and acquires a universal value.

\section{THINGS FALL APART (1958) - IMPLACABLE REJECTION OF THE GREAT OTHER}

The culture-specific elements of the $19^{\text {th }}$ century Igbo society are nowhere better described than in Things Fall Apart (1958). For Whittaker and Msiska, "part one of the novel is not only the longest section of the narrative, it also provides much of the background material which is crucial to our understanding of Okwonkwo, 
the culture which produced him, and the ultimate tragedy of his suicide" (6). What surfaces is the idea that Achebe needed to give the natives an image and voice of their own before narrating of their life-changing encounter with the great Other represented by the colonizing power. ${ }^{9}$ In this way, he manages to demolish the colonialist surmise of an "uninscribed earth" (264) mentioned by Spivak when tackling the complex process of Othering.

The cultural information is not only picturesque; it is more important than the plot development itself because it serves the dual purpose of highlighting cultural difference and setting the ground for the future clash between the two cultures. The calm rhythm of village life is only conditioned by the cycles of the seasons and a number of rituals consolidated by the passage of time and transmitted from one generation to another. These sacred rituals keep the members of the Umofia community together and give them their distinct identity.

The first part of Things Fall Apart slowly and skilfully reconstitutes the atmosphere characteristic of the Igbo community from the daily rituals of breaking the kola nuts "for life and health, and for protection against their enemies" (Achebe, The African Trilogy 7) to descriptions of important ceremonies such as The Feast of the New Yam, "an occasion for giving thanks to Ani, the earth goddess and the source of all fertility" (28). References to the villagers' agricultural activities related to the planting and harvest of the crops are intertwined with illustrations of their religious beliefs and superstitions like consulting the Oracle, confiding in a personal god or chi, putting their faith in the protective power of priests and medicine men and offering sacrifice either to appease the fury or to attract the good will of certain deities. To lay the foundation for a solid cultural background, entire chapters are solely dedicated to the description of certain rituals and ceremonies: the Feast of the New Yam and the wrestling contest between Okonkwo's village and their neighbours (Chapters 5 and 6); an engagement ceremony (Chapter 8); the ceremonial gathering of the titled men and elders (Chapter 10); the uri or betrothal ceremony when the dowry is paid (Chapter 12); the funeral ritual (Chapter 13). Apart from these elements, culture-specific terms such as proper names or names of plants, animals, agricultural as well as musical instruments together with fragments of songs and folk tales are scattered throughout the entire text, once again ensuring the authenticity of the description and paving the way for

9 In a previous article (Chifane, Chifane 55-63), we analyzed in detail the dual construction of the O/other in Chinua Achebe's trilogy. On the whole, we used Lacan's distinction and Spivak's understanding of the dialectal process of othering to prove that the double misrepresentation of the O/other leads to the rather pathetic failure of the protagonists in all three novels. 
the emergence of the Other with the consequent implications for both Okonkwo and the entire community.

The most unexpected element of cultural specificity is perhaps the liberal organization of the decision-making process. The repetitive "Gome, gome, gome, gome" (Achebe, The African Trilogy 9) are not the words of some strange incantation, but the message of the town crier for the villagers to gather in the market square where all decisions affecting the clan were taken. For example, the egwugwo or masked spirits assume the attributions of a judge who is expected to solve all major dissensions in the clan from a marriage dispute to land cases. When Okonkwo breaks the Week of Peace by beating one of his wives, his mild punishment is contrasted with the much harsher punishments of the past or the customs of other clans.

On the one hand, Okonkwo is a respected member of the community because he possesses both physical strength and wealth, the two most important criteria in the village's social hierarchy. On the other hand, his impetuosity and impatience to listen to others fails to fit in with the wisdom of the elders or the warnings inscribed in the Igbo sayings highly praised by the Umofia clan. Okonkwo does not seem to possess one major attribute of his society, that is, the art of conversation. From the first to the last, Achebe's novels will be strewn with a variety of proverbs reflecting folk wisdom and becoming "the palm-oil with which words are eaten” (7).

Having to carry the heavy burden of a weak father, Okonkwo always feels the need to prove himself worthy of the clan. Although it breaks his heart, he takes part in the ritualistic killing of Ikemefuna only for fear of being marginalized by his people. When he accidentally kills a young man and is banished to his mother's village for seven years, Okonkwo becomes the outcast and implicitly loses all his prior rights in the clan. We have to read his exile as more than an "involuntary constraint' (Ashcroft, Griffiths, Tiffin 85); for him, it is the beginning of the end. Upon his return, he is wrong to assume that the village will follow him in his rebellion against the white man. He was excluded from the community once for disregarding its rules. Why should they follow him now when they realize their very lives are at stake in the confrontation with a higher power? Even his suicide is sanctioned by the Igbo society as an abomination, therefore no clansman will touch his body.

From such a perspective, Okonkwo's failure is not only the consequence of his inability to understand or cope with the intrusive interference of the great Other or the colonizing power. It also deals with his alienation from his own people and in more general terms, with his inability to replace the Desire of the Mother with the Name-of-the-Father, that is, to swiftly pass from the Imaginary to the Symbolic Order. Seen differently, Okonkwo is perhaps among the very few who can rise above social norms and conventions and have a glimpse of the 
Real. In this new light, his suicide is the act of a strong man who refuses the subaltern position ascribed to his people by the colonizing power.

\section{ARROW OF GOD (1964) - PARALLEL REPRESENTATION OF THE OTHER}

The six villages in Arrow of God (1964) take the name of Umuaro and unite under the patronage of Ulu because of their common fear of the Other embodied by the raids of the hired soldiers of Abam who "used to strike in the dead of night, set fire to houses and carry men, women and children into slavery" (Achebe, The African Trilogy 304). Like Okonkwo in Things Fall Apart, Ezeulu holds a special position among his people. He is the Chief Priest of Ulu and lives under the false illusion that his people will follow and protect him no matter what. In a way, he seems more prepared than Okonkwo to come to terms with the colonizing power. Although he sends his son Oduche to learn the white man's customs, he is still not willing to give up their own traditions or daily priorities:

It was I who sent you to join those people because of my friendship to the white man, Wintabota. He asked me to send one of my children to learn the ways of his people and I agreed and sent you. I did not send you that you might leave your duty in my household. Do you hear me? Go and tell the people who chose you to go to Okperi that I said no. Tell them that tomorrow is the day on which my sons and my wives and my son's wife work for me. Your people should know the custom of this land; if they don't you must tell them. Do you hear me?' 'I hear you.' (303)

Ezeulu naively assumes that he can be friends with Captain Winterbottom, the District Officer. As a consequence, his gesture of sending his son could be interpreted as an attempt not only to embrace the Other, but to make the white man learn and respect their own customs. He panic and his tone become aggressive when he understands there is no question of equality between the white men and the natives. Although it is too late, he tries to make his son be proud of his ancestry and fight against a subaltern position in his relationship with the colonizers.

Critics have noticed a description of culture specific customs and traditions, which is even more picturesque than in Things Fall Apart: "Achebe's Arrow of God is possibly his most deliberate attempt at the celebration of Igbo traditions" (Kalu 203). Ezeulu is the perfect protagonist because he assumes the role of the intermediary agent between Ulu, their most powerful deity and all the other members of the community. Although he is responsible for the most 
important village rituals (the Festival of the Pumpkin Leaves and that of the New Yam), he questions the nature of his power and authority:

It was true he named the day for the feast of the Pumpkin Leaves and for
the New Yam feast; but he did not choose it. He was merely a
watchman. His power was no more than the power of a child over a goat
that was said to be his. As long as the goat was alive it could be his; he
would find it food and take care of it. But the day it was slaughtered he
would know soon enough who the real owner was. (Achebe, The African
Trilogy 293)

In matters of war, the villagers listen to Nwaka, the most titled man. When the war with Okperi is lost because of the intervention of the white man, Ezeulu rejoices thinking his people were, in fact, punished by their own god. What Ezeulu fails to see is that he himself has fallen under the gaze of the great Other by testifying against his people and contributing to a transfer of power from their deities to the Christian God.

Achebe's greatest achievement in Arrow of God is to have paralleled the Igbo traditions with the life of the Europeans living on the Government Hill. Despite his 15 years of service in Africa, Captain Winterbottom still clings to the same stereotype and discrimination promoted by the colonialist discourse. Programmed to think of the natives in hostile terms, he sees everything as his enemy, even the weather: "But this treacherous cool wind was the great danger of Africa. The unwary European who bared himself to it received the death kiss" (318). If Ezeulu and his people live in harmony with nature, the District Commisioner has his own fear of the other as it was inoculated in his mind by the discourse of colonialism: "The objective of colonial discourse is to construe the colonized as a population of degenerate types on the basis of racial origin, in order to justify conquest and to establish systems of administration and instruction” (Bhabha 101).

Winterbottom is as inflexible as Ezeulu in his ideas about authority and power. Stuck in the glorious first days of colonization, the District Commisioner is totally against the Indirect Rule type of administration which would give the power to native chiefs. The parallelism between the two characters once again enhances the consequences of the double misrepresentations of the O/other.

The novel also displays a series of comic hybrid figures such as Corporal Matthew Nweke, Jekopu or John Nwodika. Their mimicry of the white man's language (see the use of Pidgin English) or customs often becomes absurd and ridiculous. Apart from this group of characters, the missionaries act as intermediary agents between the natives and the British administration. When Ezeulu refuses to set a date for the Feast of the New Yam, the representatives of the new religion take advantage of the situation: "They must be told that if they made their thank-offering to God they could harvest their crops without fear of 
Ulu” (Achebe, The African Trilogy 499). Obika's death and Ezeulu's madness smoothen the way to the villagers' conversion to Christianity.

The readers alone are the beneficiaries of the multiple perspective employed by Achebe in this novel. Neither the colonized nor the colonizers are aware of their misreading of the O/other's actions. Under the circumstances, both Ezeulu and Captain Winterbottom are prisoners of their automatism and inability to adapt to a changing environment.

\section{NO LONGER AT EASE (1960) - ALIENATING MIMICRY AND AMBIVALENCE}

Obi, Okonkwo's grandson, is the protagonist in the last novel of The African Trilogy. Unlike his predecessors, he ultimately surrenders to the requirements of the hybrid environment in the Nigeria of the 1950s. After British colonization, the system of social administration has turned into a bitter reflection of Homi Bhabha's concepts of mimicry and ambivalence: “[...] then colonial mimicry is the desire for a reformed, recognizable Other, as a subject of a difference that is almost the same, but not quite. Which is to say, that the discourse of mimicry is constructed around an ambivalence; in order to be effective, mimicry must continually produce its slippage, its excess, its difference” (122). In Obi's case, his failure is more than a moral personal degradation; it is the failure of an entire vitiated system leading to the protagonist's decline from a promising student to a corrupted civil servant who gets convicted for accepting bribery.

Neither the Europeans nor Obi's fellow villagers in Umuofia understand how a young man of such "education and brilliant promise could have done this" (Achebe, The African Trilogy 153). The entire novel develops as a means of clarifying the reasons behind Obi's downfall. In the Europeans' club in Lagos, Africans are theoretically accepted, but in reality, only the unnoticed stewards are present. Mr. Green, Obi's boss, gives voice to the same derogatory colonialist mentality. In his opinion, the African "has been sapped mentally and physically. We have brought him Western education. But what use is it to him?” (155). In their honesty, the members of the Lagos branch of the Umuofia Progressive Union are closer to the genuine image of the decadent administrative system the British implemented: "He should not have accepted the money himself. What others do is tell you to go and hand it to their houseboy. Obi tried to do what everyone does without finding out how it was done" (156-7).

Sent to study law in England by the people in his native village, Obi chooses literature instead and comes back with the white man's attitude and perspective on Nigeria. His journey home is an opportunity for Achebe to portray the unstable coexistence of Christian and pagan elements. Besides, Obi always felt he was the product of a hybrid village culture, oscillating between his father's dogmatic Bible lessons and his mother's folk stories. There is a space 
in-between cultures in Obi's heart and mind. The idealised Nigeria sung in his nostalgic poems during his English stay is by no means the same Nigeria he faces upon his return: "The city stands midway beyween Europe and Umuofia and creates its own highly spiced amalgamation of their different cultural ingredients" (Carroll 65). The generally dirty and smelly Lagos streets stand in sheer contrast with the luxury of the European zone where Obi's job as a civil servant secured him an apartment.

Suffocated by his own need for mimicry, Obi soon realizes his salary is not enough to handle his bills, keep a car and pay his debts to Umuofia Progressive Union. The high standard of living supposedly expected of a civil servant in a European post far exceeds Obi's financial means. Since he does not accept his personal life to fall under the old norms of his fellow villagers, he can no longer rely on their help either. As a consequence, the only way out is to abdicate from his principles and accept bribery. His failure springs out of a totally misshapen appropriation of the O/other. In rejecting Clara as an osu, an outcast, Obi's father proves that his pagan beliefs are much stronger than his life-long professed Christianity and allegiance to the colonizers' civilizing ideas. Unable to return to his origins, Obi is also incapable of fully embracing the Other. In the end, he loses not only Clara, but his freedom, too. In the end, his imprisonment needs to be read as the outcome of his alienation and hybrid condition.

\section{A MAN OF THE PEOPLE (1966) - A RADIOGRAPHY OF ABUSE AND CORRUPTION}

Readers in general and literary critics alike have noticed the stylistic difference between the African trilogy and Achebe's later novels, A Man of the People (1966) and Anthills of the Savannah (1987). For example, Carroll highlights the fact that such a differentiation becomes visible even earlier, starting with the last novel of The African Trilogy: "All four are political novels, but when we group them in this way it is apparent that the two set in the earlier period describe attacks, both internal and external, upon the traditional Igbo way of life, while the two later novels, far more pessimistic in tone, diagnose the after-effects of this conflict in the modern state" (119).

The dystopian nature of Achebe's A Man of the People is clear from the very beginning since the action takes place in an unnamed, newly independent West African country in the 1960s. The new political class is primarily interested in exploiting the Africans' nationalism and the streak of native cultural treasure. The bitter irony carried by the title of the novel and the sheer sarcasm of the first paragraph of Chapter One are soon to be unraveled by the behaviour of Chief the Honourable M. A. Nanga, the Minister of Culture. The man who is supposed to be in charge of promoting the cultural values of his 
country is, in effect, a roguish opportunist with no culture at all or any kind of interest in his people: "No one can deny that Chief the Honourable M. A. Nanga, MP, was the most approachable politician in the country. Whether you asked in the city or in his home village, Anata, they would tell you he was a man of the people. I have to admit this from the outset or else the story I'm going to tell will make no sense" (Achebe, A Man of the People 1).

The first encounter between Chief Nanga and his former pupil Odili Samalu, currently a teacher at the Anata Grammar School seems to place them at opposite poles. The latter's idealism makes him totally reject the corrupt system whose clear exponent Chief Nanga is. As the story unfolds, the readers realize that as the first-person narrator, Odili is not exactly the most reliable type of narrator. His overall intentions of laying the blame on Chief Nanga prove to be a means of justifying his own actions and his own immersion in the corrupt system of which he is so critical at the onset of the story.

What Achebe achieves in both A Man of the People and Anthills of the Savannah is to provide a radiographic description of corrupt and abusive political systems where people find themselves entrapped in a never-ending vicious circle of subservience and misfeasance. Chief Nanga's visit to Anata Grammar School offers Odili the chance to express his disillusionment with the current state of affairs. His complaints range from the principal's insistence for the students and teachers to obediently stand in line during the visit to the larger critical overview of the political events of the last years.

Retrospectively, Odili identifies the strategy of artificially creating a public enemy typical of any dictatorial regime: when it suited his purposes, the Prime Minister blamed two-thirds of his cabinet and turned them into "conspirators and traitors who had teamed up with foreign saboteurs to destroy the new nation" (3). In a subsequent remark, the narrator notices that all the dismissed ministers were "university people and highly educated men" (4). The cutting from a newspaper article Odili uses as proof of his observations emphasizes the politicians' use of the anti-colonial discourse to justify their abusive actions:

Let us now and for all time extract from our body-politic as a dentist extracts a stinking tooth all those decadent stooges versed in text-book economics and aping the white man's mannerisms and way of speaking. Our true leaders are not those intoxicated with their Oxford, Cambridge or Harvard degrees but those who speak the language of the people. Away with the damnable and expensive university education which only alienates an African from his rich and ancient culture and puts him above his people... (4)

Pompous language backed by shocking similes, exaggerations and binary oppositions becomes a part of the manipulation strategy used by the politicians 
in power to induce certain ideas to the public such as the one that being a minister does not necessarily require being a specialist: "What mattered was loyalty to the party" (4). Accordingly, reality is distorted and an alternative version of the facts is made available to the general public; for instance, the exMinister of Finance's discourse is completely changed by the newspapers to turn him into "the boastful villain" (4) the Prime Minister wanted.

Although this retrospective overview is meant to show Odili's condemnation of politicians such as Chief Nanga, his readiness to accept the latter's invitation to be his guest for a while reveals a discrepancy between his previous thoughts and his concrete attitude. The implicit idea is that the reason why Odili accepts Chief Nanga's proposal is the opportunity for the latter to intervene on his behalf and speak to the Minister for Overseas Training who could offer him a scholarship for a post-graduate course in London.

While Odili seeks to use his narration as a means of denouncing what he sees as Chief Nanga's outrageous behaviour, he does not realize that he reveals a lot of details about his own personality, too. The problem is that the details he reveals about himself do not exactly do him any honour. On the contrary, Chief Nanga's bonhomie becomes tolerable in comparison with Odili's superficiality and false pretenses to honesty and correctness. Besides, as the readers soon learn, Odili does not belong to a family of high moral values as the one he invokes. Quite the opposite, he is the son of a retired District Interpreter who acted like a mediator between the white men and the natives and who shamelessly used his position to gain material profit from the other villagers:

My father was a District Interpreter. In those days when no one understood as much as 'come' in the white man's language, the District Officer was like the Supreme Deity, and the Interpreter the principal minor god who carried prayers and sacrifice to Him. Every sensible supplicant knew that the lesser god must first be wooed and put in a sweet frame of mind before he could undertake to intercede with the Owner of the Sky.” (25)

Growing up without a mother and holding an insignificant position in his father's family of many children may explain Odili's cold and indifferent attitude to women. He sees his girlfriend Elsie as a sexual trophy and he appreciates her solely on her availability and lack of demands. His emotional aridity accounts for his lack of reaction on the night of what seems like Elsie's rape by Chief Nanga; although he hears Elsie crying his name for help, he prefers to pretend she spent the night with Chief Nanga out of her own free will and not because she was forced to. In spite of the fact that he leaves Chief Nanga's house after the incident, he does not do anything to atone for the girl's distress. What is more, the readers cannot be sure if the love Odili professes for Edna is genuine or only a means of revenge against Chief Nanga as she was to 
become his second wife. His political involvement and subsequent campaign against Chief Nanga are part of his revenge plan, too.

Step by step, Odili is engulfed by the routine of the same corrupt system to which Chief Nanga belongs: he hires armed bodyguards or provides money for bribing officials. The confusion of his final confrontation with Chief Nanga is the prelude to the anarchy encompassing the country and leading to a staged coup. With Chief Nanga's arrest, Odili did not necessarily triumph. He reiterates his disillusionment with politics and politicians, but readers are also aware of his newly acquired cynicism which may turn him into the new Chief Nanga.

\section{ANTHILLS OF THE SAVANNAH (1987) - A GLOOMY VERSION OF OPPRESSION AND AUTHORITARIANISM}

Power relationships and the way they shape human character and influence the development of human interaction acquire a much darker dimension in Anthills of the Savannah (1987). Chinua Achebe wrote this novel after a twenty-one year gap. In the respective period, he probably sought a fictional form that could best reflect the social and political transformations of his beloved Africa.

Similarly to A Man of the People, Achebe's last novel takes place in the imaginary African state of Kangan during the years of military rule. The readers have the unique opportunity to witness the decisions taken at the very top of such a political regime. At the centre of the novel there is a triumvirate of friends, former school colleagues at Lord Lugard College: Kangan's head of state, Sam, known as His Excellency or H.E., who has been installed by a coup against a corrupt civilian government; Ikem Osodi, a poet born in the droughtridden province of Abazon and currently the voice of the people as the editor of the National Gazette newspaper and Christopher Oriko, the Commissioner for Information who pointlessly seeks to find a balance between the actions of his two friends and ultimately finds himself dragged into a fight that has only one possible outcome.

The polyphonic structure of the novel supports the description of all the ups and downs of the social and political unrest characterizing the African state in the story and by extension any oppressive regime whose leaders become obsessed with the idea of control and power and would stop at nothing in achieving their aims. Accordingly, the task of narration rests with the so-called witnesses Ikem and Christopher doubled by the account of Beatrice, Senior Assistant Secretary in the Ministry of Finance, who is Chris's girlfriend and a friend of Ikem's; occasionally, an authorial voice intervenes to provide bits and pieces of information.

The first chapter of the novel resembles its counterpart in A Man of the People. Both of the authoritative figures in these novels are portrayed directly by two witnesses to the exercise of power they perform during their social and 
political meetings. If in A Man of the People, Chief Nanga enjoys a triumphant arrival at the Grammar School of Anata and knows how to use his personal charisma to his advantage, in Anthills of the Savannah the comic satire of the previous novel turns into something more sinister. Sam, the military ruler of Kangan treats the members of his civilian cabinet like children and maintains an atmosphere of terror among the honourable commissioners who are even afraid to move or speak at all nowise express any personal point of view.

The scene with the Honourable Commisioner for Education remains a memorable example in illustrating the kind of blind submissiveness induced by the perpetrators and promoters of authoritarian regimes:

On my right sat the Honourable Commissioner for Education. He is by far the most frightened of the lot. As soon as he had sniffed peril in the air he had begun to disappear into his hole, as some animals and insects do, backwards. Instinctively he had gathered his papers together and was in the very act of lifting the file-cover over them and dragging them into his hole after him when his entire body suddenly went rigid. Stronger alarms from deeper recesses of instinct may have alerted him to the similarity between his impending act and a slamming of the door in the face of His Excellency. A fantastic thing happened then. He drops the file cover in such panic that everyone now turns to him and sees him perform the strangest act of all: the scattering again of his Council Papers in panic atonement and restitution for the sacrilege he has come so close to committing. Inadvertently. Then he glances round the table until his eyes meet His Excellency's and fall dead on the mahogany. (Achebe, Anthills of the Savannah 2-3)

The narrator is Christopher Orico, Sam's friend and Commissioner for Information in the cabinet. He shares with Odili from A Man of the People the same discontent and disillusionment with the current state of affairs as well as the same detachment and passivity when it comes to fight for changing things. They both have their brief revelatory moments when they feel obliged or forced by circumstances to take action; they are both faced with the loss of one of their friends (the lawyer Max Kulamo who introduces Odili into the Common People's Convention and makes him their candidate in the local elections and the poet and editor Ikem Osodi who is falsely accused of being involved in a suspected coup plot as a pretext for suspending his newspaper editorials and finally killed by Sam's people who were sent to rampage his house and detain him).

The sycophancy and simulacrum of the cabinet meeting are exposed by the arrival of the mutinous crowd accompanying the delegation sent by the Abazon province to beg of the Head of State to meet them and help them with the terrible drought affecting their region. For Carroll, this delegation from 
Abazon does not pose a real threat to Kangan's leader. It is only the beginning of the end for him because of his disproportionate reactions to their visit and the ulterior measures he is wrongfully advised to take against them: "It is only an innocuous delegation from Abazon but it represents the other, that which expresses dissent and has been denied. The President's panic and the obsequious apologies of his advisers presage the inevitable end of his dictatorial rule" (169). The six leaders of this delegation are later accused of being involved in an illegal march on the Presidential Palace and consequently arrested and held at Bassa Maximum Security Prison. What is more, Ikem himself is accused of masterminding a coup attempt together with "a group of disgruntled and unpatriotic chiefs in the Province of Abazon" and "certain foreign adventurers" (161). Once the fictitious story becomes the official version and publicly accepted truth, there is no end to possible additions, distortions or any other kind of inflorescences; on the same wavelength, there is no surprise when Chris himself is forced to leave Beatrice and his house as he is wanted by security officers in connection with the recent coup plot.

Chinua Achebe's merit in Anthills of the Savannah is to have minutely depicted the development and demise of an abusive regime through the story of three friends whose fate is doomed the moment one of them holds the reins of absolute power and is so intoxicated by this mirage that he decides to sacrifice his own friends whom he now perceives as a threat to his ambitions. He holds a grudge against Ikem and the people of Abazon for not supporting his referendum for life presidency and is willing to sacrifice Chris too when he refuses to sign Ikem's dismissal. What both Ikem and Chris fail to notice until it is too late is that Sam is no longer their twenty-five year-old friend, but "a baby monster" (10) as Chris remarks when he starts understanding "the remarkable metamorphosis of His Excellency” (9). Even more eloquently, Sam himself rebukes his friends for the failure of his life presidency referendum and lets them have an insight into the magnitude of his illusionary dream of power. In spite of Chris's attempt to reason with him and remind him that in fact he did not want to be Life President at first, he plunges into his madness even more: "I didn't, he said, and you know I didn't but the moment it was decided upon you had a clear responsibility, you and Ikem, to see it succeed. You chose not to" (141). Belatedly, Chris realizes that Sam's power frenzy is no longer under control and would lead him to a most horrific death during the real coup taking place while Chris is on the run to Abazon. Meanwhile, Sam is "kidnapped from the Palace by 'unknown persons', tortured, shot in the head and buried under one foot of soil in the bush" (209). Where Sam fails because of his lust for power and Ikem because of his unabated idealism, Chris fails because of the impossibility of leading an ordinary life in the midst of a dictatorial regime.

As if to end the circle that started with the white man's arrival in the village of Umuofia in Things Fall Apart, Ikem's anti-lecture “The Tortoise and 
the Leopard - a political meditation on the imperative of struggle" was inspired by the story told by one of the leaders of the Abazon delegation and insists on the idea of tolerance, accepting diversity and embracing the O/other: "[...] whatever you are is never enough; you must find a way to accept something however small from the other to make you whole and save you from the mortal sin of righteousness and extremism" (147). Otherwise, on a universalist scale, any human enterprise which fails to understand and accept the O/other will only lead to chaos and collapse as trustfully anticipated by Achebe in the few lines from W.B.Yeats's The Second Coming which he chooses as the motto of Things Fall Apart:

Turning and turning in the widening gyre

The falcon cannot hear the falconer;

Things fall apart; the centre cannot hold;

Mere anarchy is loosed upon the world.

Paradoxically, the one who survives to tell the story of the three friends is Beatrice, who rediscovers the value of the connection with the ordinary people and the reward of true friendship: "starting as a civil servant she is transformed by events into a prophetess who articulates the mythic pattern which emerges from the general confusion" (Carroll 175). Early in the story, she senses the three men's hubris of identifying themselves with their country and warns Chris of their tragic futures: "And I see trouble building up for us. It will get to Ikem first. No joking, Chris. He will be the precursor to make straight the way. But after him it will be you. We are all in it, Ikem, you, me and even Him” (Achebe, Anthills of the Savannah 109).

In the second half of the novel, Achebe focuses not only on the protagonists' personal revelations, but also, more importantly, on the ordinary people's reactions to the brutality of an oppressive regime, reactions ranging from acceptance and resignation to resistance, revolt and solidarity. Protected by taxi drivers, students and their modest friends, Chris begins to understand the depth of their former estrangement and alienation: "Why did we not cultivate such young men before now? Why, we did not even know they existed if the truth be told! We? Who are you? The trinity who thought they owned Kangan [...]" (183). The pidgin English used in the conversations with any of the ordinary people coming in the protagonists' way is a sign of not only their hybridity, but of their hybridity seen as an example of the potential benefits of a middle way based on tolerance and mutual understanding. Chris's bus journey to Abazon is his true chance of getting aquainted with the life of the oppressed. His death in the attempt to stop a drunken policeman from raping a girl could be read as a redemptive action for all his previous indifference to the subalterns as either women or the oppressed in general. It is at this point that the tragic fate of the 
three former friends is transformed into a lesson carrying a universal message, drawing people's attention to their own recklessness and the necessity to learn from the past and stories such as this:

So why do I say that the story is chief among his fellows? The same reason I think that our people sometimes will give the name Nkolika to their daughters - Recalling-Is-Greatest. Why because it is only the story can continue beyond the war and the warrior. It is the story that outlives the sound of war-drums and the exploits of brave fighters. It is the story, not the others, that saves our progeny from blunduring like blind beggars into the spikes of the cactus fence. The story is our escort; without it, we are blind. Does the blind man own his escort? No, neither do we the story; rather it is the story that owns us and directs us. (119)

Chris's vision of the scorched anthills of the savannah makes him realize the shalowness of his former approach to life and ultimately accept his death as liberation. The same search for an answer and aspiration to freedom are rendered through Beatrice's rhetorical question when she finally breaks the silence after Chris's death: "What must people do to appease an embittered history?” (211). The naming ceremony of Elewa and Ikem's child at the end of the novel carries an optimistic message in spite of the harsh dystopian realities described throughout the story.

\section{CONCLUSIONS}

If The African Trilogy was mainly designed to deliver an anticolonial message, $A$ Man of the People and Anthills of the Savannah move beyond the elements of cultural specificity and the consequences of the clash between the colonized and the colonizer.

In Things Fall Apart, Achebe thoroughly describes the Igbo culture insisting on the different facets of community life. Okonkwo emerges as a respected member of Umuofia, but his pride and impatience condemn him to exile and ultimately to a singular position in the ensuing conflict with the colonizing power. His suicide is not necessarily only a sign of his inflexibility and alienation from his own clan; it is also the gesture of a man who refuses compromise and has the vision of the subaltern condition awaiting the natives in the new social organization.

Driven by his own ambitions and drifting away from his own people, Ezeulu in Arrow of God unwillingly becomes the agent of the great Other. His refusal to name the date of the New Yam Feast facilitates the villagers' conversion to the new religion. In addition, the parallel between Ezeulu and Winterbottom reveals the double misrepresentation of the O/other. 
Misconceptions and stereotypical thinking are responsible for defective communication and disproportionate reactions.

No Longer at Ease features another protagonist who has difficulties in coming to terms with his hybrid condition and mixed identity. Forced to follow the rules of a vitiated administrative system, Obi cannot fully ambrace the world of corruprion, nepotism and bribery. His failure is the direct consequence of an alienating and degradating mimicry.

To the bitterness of Obi's story, Achebe adds sarcasm and satire in Odili's account of the events in A Man of the People. The first-person narration aims at denouncing the abuse and corruption of a West African political regime of the 1960s. Apart from exposing Chief Nanga's outrageous misconduct, Odili reveals his own weaknesses and gradual moral degradation. Like Obi's, Odili's idealism ends up in cynicism and disillusionment.

Last but not least, Anthills of the Savannah is Achebe's most complex and interesting novel. The polyphonic structure and multiperspectivism support the universalist message of the novel. All three protagonists share a tragic fate even if for apparently different reasons. Ikem becomes the victim of an authoritarian regime he has the courage to contest, whereas Sam has the predictable fate of any dictator blinded by his lust for power. Even Chris is sentenced to death the moment he tries to lead a neutral life side by side with abuse and oppression. In the end, he is the only one who acknowledges the importance of understanding and accepting the O/other.

Despite Achebe's own rejection of the universal label attached to his novels, they undoubtedly transcend the social and poilitical turmoil of African history, plunging into universality. His stories become an illustration of people's struggle to move beyond the boundaries of the Lacanian Symbolic Order and enter the realm of the much sought Real.

\section{Works Cited}

Achebe, Chinua. The African Trilogy. New York: Everyman's Library, 2010. Print. Achebe, Chinua. A Man of the People. New York: Penguin Books, 2001. Print.

Achebe, Chinua. Anthills of the Savannah. New York: Penguin Books, 2001. Print.

Achebe, Chinua. Morning Yet on Creation Day. New York: Doubleday, 1975. Print.

Achebe, Chinua. "The Novelist as a Teacher". New Statesman 29 January 1965. Morning Yet on Creation Day. New York: Doubleday, 1975. Print.

Ashcroft, Bill, Griffiths, Gareth and Helen Tiffin. The Empire Writes Back. London: Routledge, 2002. Print.

Bhabha, Homi K. The Location of Culture. London: Routledge, 1994. Print.

Carroll, David. Chinua Achebe. Novelist, Poet, Critic. London, Macmillan Press Ltd., 1990. Print. 
Chifane, Cristina and Liviu-Augustin, Chifane. "Chinua Achebe’s African Trilogy and the Dual Construction of the O/other.” B.A.S./ British and American Studies. Vol. XXIV. Timișoara: Editura Diacritic, 2018. 55 - 63. Print.

Kalu, Anthonia C. "The Priest/Artist in Achebe's Arrow of God." Emerging Perspectives on Chinua Achebe, Vol. 1. Ed. Ernest Emenyonu. Trenton: Africa World Press, Inc., 2004. 195-207. Print.

Fanon, Frantz. Black Skin, White Masks. Trans. Richard Philcox. New York: Grove Press, 2008. Print.

Fanon, Franz. The Wretched of the Earth. Trans. Constance Farrington. London: Penguin Books, 2001. Print.

Lacan, Jacques. Écrits. The First Complete Edition in English. New York: W.W.Norton \& Company, 1996. Print.

Spivak, Gayatri Chakravorty. "The Rani of Sirmur." Europe and its Others. Vol. 1, Proceedings of the Essex Conference on the Sociology of Literature July 1984. Ed. Francis Baker. Colchester: University of Essex, 1985. 247-72. Print.

Whittaker, David and Mpalive-Hangson Msiska. Chinua Achebe's Things Fall Apart. New York: Routledge, 2007. Print. 